\title{
The Microbial Production of Expertise in Meiji Japan
}

\author{
by Victoria Lee*
}

\begin{abstract}
Microbes as an object of knowledge and the scientist as an institution of authority did not exist in Japan before the nineteenth century. This essay considers the formation of these two modern categories by looking at their boundaries in late Meiji Japan (1868-1912). Charting transformations in the landscape of brewing expertise, the processes that brewing technicians used to produce molds as commodities, and finally the critical reaction of the slime-mold naturalist Minakata Kumagusu who opposed the philosophical foundations of disciplinary science, it argues that the co-production of the microbe and the scientist as new categories reveals a convergence between imported European ideas and earlier Tokugawa-era (1603-1868) commercial developments. Their convergence in turn-of-the-century Japan is highly suggestive of the ways in which the modernity of scientific institutions is entangled with industrial capitalism.
\end{abstract}

\section{INTRODUCTION}

Microbes as a concept did not exist in Japan before the nineteenth century, but brewers of sake, soy sauce, miso, and other products had handled microbes - visible en masse as rice mold formations - with specialist skill, understanding them as essential raw materials in the brewing process, like water or rice. By the first decade of the twentieth century, brewers faced a new landscape of microbe species that were divided into "useful ones" [yūeki naru mono] and "harmful ones" [yūgai naru mono]. ${ }^{1}$ Within a species, microbe varieties were characterized by their physiological as well as morphological differences, which coincided with their role in different industries: the fungi used in the sake industry formed more sugars, whereas the fungi used in the soy-sauce

* Department of History, Ohio University, Bentley Annex 452, Athens, OH 45701-2979; leev (a) ohio.edu.

This essay includes material from my article, "Mold Cultures: Traditional Industry and Microbial Studies in Early Twentieth-Century Japan," in New Perspectives on the History of Life Sciences and Agriculture, ed. Denise Phillips and Sharon Kingsland (Cham, 2015). It is reprinted here with permission.

${ }^{1}$ Takahashi Teizō, Jōzō bairon [Theory of brewing molds] (Tokyo, 1903), chap. 1, pp. 3-4. On comparable trends in entomology, see Setoguchi Akihisa, Gaichū no tanjō: Mushi kara mita Nihonshi [Birth of the harmful insect: Japanese history through the insect] (Tokyo, 2009).

- 2018 by The History of Science Society. All rights reserved. 0369-7827/11/2018-0009\$10.00 
and tamari industries formed more amino acids, chemicals associated with protein breakdown and flavor. ${ }^{2}$ These novel species were named by scientists, their existence conveyed to brewers in manuals and trade magazines, their strains to be distributed from national and prefectural experiment stations as well as made by brewing technicians.

Among the harmful were the "hiochi microbes" (hiochi kin; hiochi being the term for spoilage, when the sake "dropped" the fire put in during the heating process known as hiire). ${ }^{3}$ Among the useful, specialists in the brewing industry had produced and sold the rice mold $k \overline{o j i}$, as well as its dried spores known as moyashi (or in the modern era, tanekojji) since the thirteenth century, which by the twentieth century were named $A s$ pergillus oryzae. These were only a part of the diversity of "useful fermentation microbes" [y $y \bar{u} y \bar{o}$ hakkōkin] produced in Asia. ${ }^{4}$

This essay considers the formation of two modern categories in Japan by looking at their boundaries in the early twentieth century: the "microbe" as an object of knowledge, and the "scientist" as an institution of expertise. Both of these new categories relied on a notion of "nature" that had no Japanese-language equivalent in the Tokugawa period (1603-1868) - a word that referred to the whole of material reality as something universal, as well as something distinct from "society." The microbe as an object of knowledge reflected a novel ontological division in the boundary between cellular life and the environment, which the new conception of nature allowed. The scientist as a socio-institutional category was a new kind of expert who specialized in nature. Yet both categories of "microbe" and "scientist" were not only linked to European categories by a self-consciously Western refashioning of Japan's political economy in the Meiji period (1868-1912); they were also shaped significantly by conceptions that had emerged amid the vibrant protocapitalism of the Tokugawa era.

The procedures and assumptions of commercial brewers that had been developing over several centuries and those of academic microbe scientists in turn-of-the-century Japan display a striking, suggestive convergence. In his study of early modern Japanese honzōgaku (materia medica), Federico Marcon points out the homology between species and commodities as abstractions concealing human labor. He argues that the production of species transformed the natural world into "a collection of objects to analyze, represent, manipulate, control, and produce . . . devoid of any metaphysical or sacred aura." In the Meiji era, the parallel between the species of fermentation microbes produced by scientists and the commercial brands of spores produced by tanekoji makers became a literal one: both were microbes isolated, identified, and

\footnotetext{
2 Teizo Takahashi, “A Preliminary Note on the Varieties of Aspergillus oryzae," J. Coll. Agr. Imperial Univ. Tokyo 1 (1909): 137-40; Teizo Takahashi and Takeharu Yamamoto, "On the Physiological Differences of the Varieties of Aspergillus oryzae Employed in the Three Main Industries in Japan, Namely Saké-, Shôyu-, and Tamari Manufacture," J. Coll. Agr. Imperial Univ. Tokyo 5 (1913): 151-61.

${ }^{3}$ Teizo Takahashi and Kin-ichiro Sakaguchi, Summaries of Papers, Committee of Commemorative Meeting of 35 Year's Anniversary of Professor Kin-ichiro Sakaguchi (Tokyo, 1958), 8, item 30.

${ }^{4}$ Saitō Kendō, "Higashi Ajia no yūyō hakkōkin" [Useful fermentation microbes of East Asia], Tōyō gakugei zasshi 23 (1906): 507-20.

${ }^{5}$ Federico Marcon, The Knowledge of Nature and the Nature of Knowledge in Early Modern Japan (Chicago, 2015), 276-7.

${ }^{6}$ Ibid., 296-7.
} 
preserved by methods of pure culture, and characterized not only by their morphology as experienced by the senses or under a microscope, but by their physiological activity in the context of brewing processes. Thus microbes in Japan became living workers as much as pathogens. ${ }^{7}$ Likewise, the role of the microbe scientist within the modern Japanese state was not like that of the early modern intellectual, but built instead on that of the technical specialist within the brewery: a manager of material production for capital accumulation, now on a national level.

Tracing the coproduction of the microbe and the scientist as new categories in light of the convergence between imported European ideas and Tokugawa-era commercial developments, I argue that this convergence in turn-of-the-century Japan is highly suggestive of the ways in which the modernity of scientific institutions is entangled with industrial capitalism. As Lee Vinsel and Sarah Milov discuss elsewhere in this volume, the entanglements of scientific investigation and capitalism created new entities for understanding: the accident-prone driver, the secondhand smoker, and, in this case, the microbe. ${ }^{8}$ At the same time, the emergence of new entities came hand in hand with new modes of scientific expertise. For example, Vinsel traces the formation of a niche for applied psychologists in auto safety testing, while William Deringer and Paul Lucier examine the construction of mathematical and geological expertise respectively, in spaces opened up by financial and capitalistic enterprises. ${ }^{9}$ What is especially revealing in the case of Japanese fermentation science is the continuity of both new categories - the microbe and scientific expertise - with earlier protocapitalist practices.

The first part of the essay charts the transformation in the landscape of brewing expertise following the rise of the microbe as a conceptual force and the formation of the scientist as a specialist authority. It then examines the significance of these new categories in the work of two figures who operated outside disciplinary institutions of science, the brewing technician Konno Seiji and the naturalist Minakata Kumagusu. Konno Seiji's brewing work illuminates the processes for producing molds as commodities and their continuity with the new scientific methods. Minakata Kumagusu's slime mold studies explicitly opposed the assumptions of disciplinary microbiology as well as science's established role in the state. Minakata's research highlights the emerging contours of academic science not because he exemplified them, but because he showily reacted against them, by developing alternative approaches to studying molds that directly contrasted with the work of academic scientists. The production of the conceptual and social boundaries of the new microbial entity cannot be separated from those of the new scientific expert; this essay offers a joint portrait of both.

\footnotetext{
${ }^{7}$ Victoria Lee, "Mold Cultures: Traditional Industry and Microbial Studies in Early TwentiethCentury Japan," in New Perspectives on the History of Life Sciences and Agriculture, ed. Denise Phillips and Sharon Kingsland (Cham, 2015), 231-52.

${ }^{8}$ Lee Vinsel, "Safe Driving Depends on the Man at the Wheel': Psychologists and the Subject of Auto Safety, 1920-55"; Sarah Milov, "Smoke Ring: From American Tobacco to Japanese Data," both in this volume.

${ }^{9}$ William Deringer, "Compound Interest Corrected: The Imaginative Mathematics of the Financial Future in Early Modern England"; Paul Lucier, "Comstock Capitalism: The Law, the Lode, and the Science," both in this volume.
} 


\section{LANDSCAPES OF EXPERTISE}

By the close of the Tokugawa period, soy-sauce, miso, and especially sake brewing accounted for by far the highest values of production in the entire nonagricultural manufacturing sector in Japan, easily surpassing textile weaving and raw silk production. At the beginning of the twentieth century, among those wealthiest people who came by their riches through industrial manufacturing, there were more brewers than any other occupation, and their numbers rivaled those in rising modern industries such as cotton spinning. ${ }^{10}$ The largest brewers emerged during the second half of the Tokugawa period in Nada (near Kobe, west of Kyoto and Osaka) in the Kansai region of western Japan for sake and in Noda and Chōshi (east of Tokyo) in eastern Japan for soy sauce. Those breweries, which were located in rural areas, employed dozens of workers from the vicinity and were becoming increasingly mechanized.

In the late Tokugawa period, Japan was one of the most highly urbanized societies in the world, with numerous large cities and castle towns that formed part of a national network of consumption and distribution. ${ }^{11}$ The leading breweries competed with each other on scale as well as quality to ship their goods to major urban markets, particularly the largest cities: Edo (renamed Tokyo after the Meiji Restoration), Kyoto, and Osaka. National markets grew first for sake, while the use of commercial rather than homemade soy sauce was initially more common in eastern than western Japan, and miso production was dominated by the home kitchen into the twentieth century. ${ }^{12}$ However, brewing was a multilayered industry: outside of urban areas, village residents bought mainly from small or medium-scale local producers. In rural areas there was also widespread home brewing of unrefined sake [nigorizake or doburoku], which farm workers would drink early in the day as it was thought to give them energy for heavy labor on the farm. ${ }^{13}$

The brewing of rice into liquor, involving the kojii mold that grew on the rice, had been performed in Japan for perhaps two millennia. The specific origins of koji brewing were not known, although there were clear connections with mold brewing of grains on the Asian continent. In the medieval period, specialist rice wine brewers emerged in Kyoto to supply the aristocracy for ceremonial or medicinal purposes, and by the fourteenth century, commercial sake was also produced in the countryside for public drinking on market days and special occasions. ${ }^{14}$ Sake breweries developed especially in urban areas with access to rice, such as port cities in the Kansai region that saw large commercial rice transactions, or nearby temple towns that could sell their products in Kyoto. In the seventeenth century, the establishment of the Tokugawa shogunate based in Edo brought the growth of cities across the country, as sam-

\footnotetext{
${ }^{10}$ Masayuki Tanimoto, "Capital Accumulation and the Local Economy: Brewers and Local Notables," in The Role of Tradition in Japan's Industrialization: Another Path to Industrialization, ed. Masayuki Tanimoto (Oxford, 2006), 301-22, on 301-2.

${ }^{11}$ David L. Howell, "Urbanization, Trade, and Merchants," in Japan Emerging: Premodern History to 1850, ed. Karl F. Friday (Boulder, Colo., 2012), 356-65, on 356-7.

${ }^{12}$ Penelope Francks, "Inconspicuous Consumption: Sake, Beer, and the Birth of the Consumer in Japan,” J. Asian Stud. 68 (2009): 135-64, on 149.

13 Tanimoto, "Capital Accumulation" (cit. n. 10), 301-5.

${ }^{14}$ Katō Hyakuichi, "Nihon no sakazukuri no ayumi" [History of sake brewing in Japan], in Nihon no sake no rekishi: Sakazukuri no ayumi to kenkyū [History of sake in Japan: Sake brewing history and research], ed. Katō Benzaburō (Tokyo, 1977), 41-315, on 168; Francks, "Inconspicuous Consumption" (cit. n. 12), 153.
} 
urai were required to live in castle towns to serve their domain lord. Though officially political authorities encouraged commoners merely to farm in order to produce taxes for their lords, over time the domains came to be chronically dependent on prominent merchants for loans and contributions, in return offering privileges such as the recognition of trade monopolies for certain commodities within regional markets. Thus the commerce that flourished in the Tokugawa period came to be dominated by merchants with ties to domain officials, initially wholesalers based in the cities.

By the mid-eighteenth century, the economy experienced a host of changes that historians have documented as a distinctively rural-centered, protoindustrial, protocapitalist transformation. ${ }^{15}$ Around the country, there was a dramatic growth in the number of rural households that produced goods for sale in distant markets, typically engaging in side industries along with agriculture. Through such small-scale manufacturing activities, as well as moneylending and experimentation with farming techniques, a number of rural elites began to amass substantial wealth. Major urban centers declined or stagnated as "country places" rose on their outskirts, challenged the hold of city merchants, and became centers of vibrant consumption as well as production. Many domain authorities by this time had come to tolerate and even promote commercial growth, since they were increasingly dependent on commoner elites for funds and trading services. As interregional competition for national markets intensified, domain authorities could turn a blind eye when rural elites usurped urban monopolies, or encourage market-oriented production in the local region by aiding the introduction of new technologies, as well as inviting skilled experts from —or having observers travel to-more advanced regions. ${ }^{16}$

In this period Nada sake brewers, who usually began as wealthy landowners and rural merchants, competed with nearby urban establishments in Osaka, Nishinomiya, Ikeda, and Itami. Nada villages had several geographical advantages. They had access to water power that could drive rice-polishing machines, they were able to take advantage of a winter wage labor force when repeated restrictions by political authorities forced the concentration of sake brewing into the agricultural off-season (which incidentally produced a better-quality sake despite increasing the fermentation time), and they were located close enough to city markets as well as growing rural markets. ${ }^{17}$ Across the country, refined sake was no longer a luxury reserved for the aristocratic and samurai classes; it came to accompany meals in restaurants and teahouses as well as in rural households when families entertained visitors. Izakaya bars flour-

\footnotetext{
15 Thomas C. Smith, Native Sources of Japanese Industrialization, 1750-1920 (Berkeley and Los Angeles, 1988); Akira Hayami, Japan's Industrious Revolution: Economic and Social Transformations in the Early Modern Period (London, 2015); Hayami Akira, "Keizai shakai no seiritsu to sono tokushitsu" [The emergence of the economic society and its characteristics], in Atarashii Edo jidaishizo $o$ motomete [Searching for a new historical view of the Edo era], ed. Shakai keizaishi gakkai (Tokyo, 1977), 3-18; David L. Howell, Capitalism from Within: Economy, Society, and the State in a Japanese Fishery (Berkeley and Los Angeles, 1995); Kären Wigen, The Making of a Japanese Periphery, 1750 1920 (Berkeley and Los Angeles, 1995); Edward E. Pratt, Japan's Protoindustrial Elite: The Economic Foundations of the Gōnō (Cambridge, Mass., 1999).

${ }^{16}$ Pratt, Japan's Protoindustrial Elite (cit. n. 15), chap. 1.

${ }^{17}$ Ibid., 71-2; Tessa Morris-Suzuki, The Technological Transformation of Japan: From the Seventeenth to the Twenty-First Century (Cambridge, 1994), 49-50; Andrew Gordon, A Modern History of Japan: From Tokugawa Times to the Present, 3rd ed. (New York, 2014), 33.
} 
ished in Edo and along major roads, while many villages hosted small breweries or at least one or two drinking establishments. ${ }^{18}$

Morohaku sake, in which white rice instead of unrefined rice was used not only in the fermentation mash (where white rice had long been used) but also in kōji making, became widespread in the seventeenth century. Morohaku brewing encouraged broader changes in labor and technology within the sake industry. ${ }^{19}$ The sharp increase in the amount of labor needed for rice polishing meant that rice polishers began to work separately from the brewing workers. Breweries began to rely on external technical specialists who were skilled in the brewing process, eventually leading to the rise of experts called tōji (head brewer). Whereas medieval kōji makers had been a separate specialist industry, in the Tokugawa period the kōji making process was integrated into the sake brewery. However, moyashi making - the making of dried $k \overline{o j i}$ spores to be used as starters for köji making - gradually emerged as an independent industry.

Brewing differed from other traditional side industries, such as textiles, in that it required relatively high levels of capital and labor. Sake and soy-sauce brewery owners needed a certain level of capital because they needed large tracts of land, buildings, and equipment such as tanks for the fermentation process, and because the brew took many months to mature. As for labor, the labor force was not family based, unlike in textiles. A contract-based, seasonal labor force came to the brewing house to brew in the winter months. The labor force was all male. Until the fifteenth century, sake brewing had been a female-gendered profession, and women had led a number of merchant guilds. By the middle of the Tokugawa period, the rise of religious ideas of pollution linked to women meant that women were banned from entering the brewery. ${ }^{20}$ The brewery owner controlled but did not himself oversee the production process. In the case of both sake and soy-sauce brewing, he left the management of production to the tōji and the kashira (deputy), whom he hired, and interfered little. The tōji and kashira recruited the annually contracted workers as well as the day laborers and oversaw the day-to-day running of the brewing house. It was the tojji, rather than the brewery owner, who was master of the knowledge of the fermentation process. ${ }^{21}$

Reflecting the understanding of stages of material change in the sake brewing process, under the tōji and kashira the employees were divided into kōji specialists, moto specialists, rice-steaming specialists, cooks for all, and day laborers. The space of the brewing house mirrored these divisions, with its different rooms. The process began with the selection of the key raw materials, water and rice. Next was kojji making, which was done by adding purchased moyashi to steamed and dampened rice, letting it sit in the warm, humid kōji room to let it begin to grow, and then putting it into wooden boxes that would be lined up on shelves in the room and leaving it for a few days, resulting in a fine-smelling, green-yellow mold. The moto as a material was difficult to achieve well and guided the fermentation process. It was made by mixing $k \overline{o j} i$

\footnotetext{
${ }^{18}$ Francks, "Inconspicuous Consumption" (cit. n. 12), 155-6.

19 Katō, "Nihon no sakazukuri no ayumi" (cit. n. 14), 212-5.

${ }^{20}$ Hitomi Tonomura, "Gender Relations in the Age of Violence," in Friday, Japan Emerging (cit. n. 11), 267-77, on 275 .

${ }^{21}$ Tanimoto, "Capital Accumulation" (cit. n. 10); Mark Fruin, Kikkoman: Company, Clan, and Community (Cambridge, Mass., 1983), chap. 1.
} 
with steamed rice and water in several stages and required regular stirring with an oar over many days. Then there was moromi making, in which kojji and moto were mixed with steamed water and rice. The ways in which this mash could be prepared were innumerable, and each brewery had its own style. Finally, the resulting liquid would be clarified by being squeezed out through a fine press into a large cask and would then be placed into storage. Hiire ("putting in fire," a heating process) would also be performed to discourage spoilage during storage. ${ }^{22}$ With the first press of the season, the brewers would hang a large green ball of fresh cedar leaves outside the brewing house, which would gradually turn brown to signify the sake's maturation. Soy-sauce making was similarly based on kōji making followed by applying kōji to steamed soybean, wheat, and water in a variety of styles. Brewery workers believed that gods were responsible for the changes in the materials that made sake and aimed to preserve the cleanliness and sanctity of the brewing space. Inside the brewery there would be a shrine devoted to a sake god. The clapping of hands in worship in front of the shrine, the exclusion of women from the space, and the changing into and out of indoor sandals when entering or leaving the brewery were all everyday precautions to ensure a smooth brew amid many possible contingencies. ${ }^{23}$

The Meiji period was a difficult time for many brewers. In the 1850 s, the United States and other Western powers coerced Japan into accepting unequal treaties by military force. Following the overthrow of the Tokugawa shogunate in 1868, the new Meiji government implemented a series of policies to promote the growth of industrial capitalism and national military modernization in order to avoid colonization by Western powers, adapting American and European institutional models under the slogan of "rich country, strong army" [ fukoku kyōhei]. Having abolished the domains in favor of a centralized system of government, as well as the status distinctions between samurai and commoners and their accompanying occupational privileges and constraints, the government dismantled the early modern guild structure through which the domains and shogunate had controlled production and commerce, lifting all restrictions on who brewed and what amount they brewed. There was a proliferation of new sake brewers, especially landlords employing tenant labor, while brewers as a whole experienced unstable fortunes. The government taxed the alcohol industry heavily, frequently raising the tax in order to meet the demands of military preparation and infrastructure building. Cheap imported alcohol flooded the markets under the unequal treaties and put further pressure on brewers. The alcohol industry became the Meiji government's greatest source of tax revenue, exceeding the land tax by the end of the nineteenth century. ${ }^{24}$

\footnotetext{
${ }^{22}$ Katō, "Nihon no sakazukuri no ayumi” (cit. n. 14), 215-29.

${ }^{23}$ Ibid., 215-6.

${ }^{24}$ Fujiwara Takao, Kindai nihonshuzōgyōshi [History of the modern sake industry] (Kyoto, 1999), 185. From the late 1920 s to the late 1930 s, Marxist intellectuals looked back upon Meiji-era capitalism in an intense debate over how it should be situated analytically. The Kōza-ha (Lectures Faction), which followed the line given by the Comintern, emphasized the feudal elements remaining in the special or hybrid case that was Japanese capitalism and argued that state institutions were upheld by a base of semifeudal production relations in the countryside. The Rōnō-ha (Worker-Farmer Faction) took a different view that placed Japanese capitalism among the imperialist finance capitalisms of the world, and that saw the Meiji Restoration of 1868 as a bourgeois revolution with roots that reached back to the Tokugawa period. See Andrew E. Barshay, The Social Sciences in Modern Japan: The Marxian and Modernist Traditions (Berkeley and Los Angeles, 2004).
} 
Private entrepreneurs, including rural elites, and the Meiji state alike invested in new capital-intensive projects during the state's push for what it saw as the late takeoff of the economy: modern banks and industries, railroads and other infrastructure. Moreover, at the local level, rural elites were nationalistic and enthusiastic as they spearheaded development efforts in the traditional sector, even though government policies favored export products over sake or soy sauce. ${ }^{25}$ In the celebrated brewing regions of Kansai, wealthy brewing improvers published manuals and trade magazines to disseminate scientific principles and new European methods, such as the use of thermometers and salicylic acid, for scaling up production and making goods competitive for export. In other parts of the country, small and medium-sized brewers similarly formed discussion societies, trade and industry associations, and producers' cooperatives. They hoped to imitate the techniques of the Nada districts and standardize quality, in order to survive the competition in local or regional markets during the volatile economic conditions of the period. $^{26}$

In the early Meiji decades, rural elites' hopes dovetailed with government initiatives, the latter of which included temporarily employing Western experts [oyatoi gaikokujin] as teachers and consultants, sending Japanese students abroad, establishing schools to teach Western-style disciplines and imperial universities to train a Japanese elite for government service, and building a series of state-owned model enterprises based on large-scale production. Rubbing shoulders with both Tokugawa political authorities and now Meiji officials, rural elites - who had sometimes been granted samurai privileges in the past - had high hopes for the greater role that they might play in the new Meiji regime. By the late 1880s, however, many of the stateowned enterprises had been sold off to the private sector (later to become the large industrial combines known as the zaibatsu) as a result of commercial failure, and prefectural agricultural schools, training centers, and experiment stations had been shut down. In addition, it was clear that a goal of state initiatives was to provide a source of employment for former samurai. A majority of the students at government schools or prefectural stations were samurai, not farmers, while high-ranking prefectural officials were generally samurai from other parts of the country. ${ }^{27}$

Led by the rural elite, the local trade and industry associations that supported improvement-of-industry movements soon turned critical of the government. In the later Meiji decades the state reversed its policies and, rather than solely prioritizing modern transplanted industries, began to encourage small- and medium-scale traditional industries in order to make them more competitive, both domestically and for export mainly to Asia. The government consolidated a network of middle-level institutions, including trade associations for disseminating information, technical colleges to train technicians for industry, and prefectural and national experiment stations that conducted research on behalf of small and medium-sized businesses. ${ }^{28}$ As historians have argued more recently, rural-based, traditional industry continued to play a significant role in the Jap-

\footnotetext{
${ }^{25}$ Pratt, Japan's Protoindustrial Elite (cit. n. 15), 35.

${ }^{26}$ Fujiwara, Kindai nihonshuzōgyōshi (cit. n. 24), 185-99.

${ }^{27}$ Pratt, Japan's Protoindustrial Elite (cit. n. 15), 37-8.

${ }^{28}$ Morris-Suzuki, Technological Transformation (cit. n. 17), 98-103; Kaoru Sugihara, "The Development of an Informational Infrastructure in Meiji Japan," in Information Acumen: The Understanding and Use of Knowledge in Modern Business, ed. Lisa Bud-Frierman (London, 1994), 75-97.
} 
anese economy well into the twentieth century alongside the modern factory system. ${ }^{29}$ In this way, state institutions built on the existent structures and energy of local rural movements - even where they came under the supervision of bureaucrats in the Ministry of Agriculture and Commerce and were dominated by the scientifically trained, who were predominantly though not exclusively samurai-and consequently "made redundant many of the rural elites' traditional roles" by the first decade of the twentieth century. ${ }^{30}$

It was in this context of industrialization and the improvement of traditional industry that science institutions took shape. As James Bartholomew notes, early on Japan's first imperial university, Tokyo University, was "institutionally innovative" in incorporating not only a powerful faculty of medicine but also a strong college of engineering (1886) and agriculture (1890) from existing institutions. In government ministries, agricultural research was especially well supported..$^{31}$ At the turn of the century, the government worked with local elites to encourage the establishment of higher technical schools as well as agricultural and industrial experiment stations. The national Brewing Experiment Station was founded in Tokyo in 1904 under the Ministry of Finance, as part of a nationwide network of regional brewing experiment stations. Among other things, it surveyed breweries, ran training courses for tōji, undertook studies of raw materials, and promoted the use of pure-cultured yeasts in sake breweries in place of moto making, centering on yeasts distributed by the related Brewing Society. ${ }^{32}$

In manuals, trade magazines, scientific books, and scholarly journals, microbes [kin] began to appear alongside their common names and species names, with sketches of their appearance under a microscope. They became the living forces of the brewing process - the kōji mold that turned starch into sugar, or the wild kōbo (yeasts) cultivated in the moto that transformed sugar into alcohol. Scientists argued that the quality of the sake was connected to the purity of the kojji, and brewers' ability to keep the kōji free from contamination..$^{33}$ Some argued that the yeasts of the moto created specific flavors of sake. ${ }^{34}$ (Brewers themselves did not accept this simplistic narrative, and to scientists it quickly became clear that there were also symbiotic lactic acid bacteria involved in the ecology of the moto. ${ }^{35}$ ) A few of the scientists who named the earliest brewing microbes included German botanist Hermann Ahlburg (a foreign consultant teaching at the Tokyo Medical School, the predecessor of Tokyo University's Faculty of Medicine) and German agricultural chemist Oskar Kellner (a foreign consultant teaching

29 Tanimoto, The Role of Tradition (cit. n. 10); Masayuki Tanimoto, "From Peasant Economy to Urban Agglomeration: The Transformation of 'Labour-Intensive Industrialization' in Modern Japan," in Labour-Intensive Industrialization in Global History, ed. Gareth Austin and Kaoru Sugihara (London, 2013), 144-75.

${ }^{30}$ Pratt, Japan's Protoindustrial Elite (cit. n. 15), 6. On the class background of scientists in the early twentieth century, see James R. Bartholomew, The Formation of Science in Japan: Building a Research Tradition (New Haven, Conn., 1989), 52-63.

${ }^{31}$ Bartholomew, Formation of Science (cit. n. 30), 93.

${ }^{32}$ Lee, "Mold Cultures" (cit. n. 7).

${ }^{33}$ Shimoyama Jun'ichirō, "Seishu no jōzō ni tsuite" [On the brewing of sake], in Jōzō taikashü [Anthology of great brewing experts], vol. 1, ed. Hirayama Kōnosuke (Tokyo, 1902), 1-10; Kozai Yoshinao, "Nihonshu jōzō no kairyō ni tsuite" [On the improvement of sake brewing], Jōzō zasshi 305 (1901): $23-7$.

${ }^{34}$ Shimoyama Jun'ichirō, "Seishu no jōzō” (cit. n. 33).

${ }^{35}$ Furukawa Sōichi, "Nyūsankin to kōbo no kyōson to kyōsei" [The coexistence and symbiosis of lactic acid bacteria and yeast], Seibutsu kōgaku kaishi 90 (2012): 188-91. Thanks to Furukawa Yasu for the reference. 
at the Komaba Agricultural School, the predecessor of Tokyo University's Faculty of Agriculture), who named Aspergillus oryzae as the kōji mold of sake. ${ }^{36}$ Saitō Kendō (a doctor in botany from the Faculty of Science of Tokyo Imperial University) named Saccharomyces soja as a soy-sauce yeast. ${ }^{37}$ Yabe Kikuji (official appraiser at the Ministry of Finance, and a doctor in agricultural chemistry from the Faculty of Agriculture of Tokyo Imperial University) named Saccharomyces sake as a sake yeast. ${ }^{38}$

All these scholars [gakusha] with doctoral degrees [hakushi] in specialist disciplines were considered to be scientists; they worked in government ministries, experiment stations, technical schools, or universities, often in a number of these, during their lifetimes. ${ }^{39}$ A microbe scientist could also have been trained in a university faculty of engineering as a doctor in applied chemistry (Tsuboi Sentarō, discussed below), a doctor in pharmacy (Shimoyama Jun'ichirō, cited above), as well as a doctor from a university faculty of medicine. When in 1902 Saitō Kendō was tasked with investigating the microbes around a possible site for the national brewing laboratory, nobody in Japan was an expert on "fermentation microbes" [hakkōkin]. Saitō copied methods from German, Danish, and Japanese books on brewing science. His research was primarily taxonomic in aim, with the goal of elucidating and classifying new microorganisms. Much of it was pioneering work because "at the time the kinds of wild fungi produced in Japan were completely unknown." ${ }^{40}$ Yet like the microbe species named above, the organisms that he found mapped onto the spaces and stages of the established brewing process. The next two sections discuss academic science's striking convergence with Konno Seiji's manufacturing research, as well as its divergence from Minakata Kumagusu's epistemologically driven questions. These trends were a result of the reorganization of investigation in Japan that came hand in hand with the introduction of the microbial entity in modern disciplinary science.

\section{PURE CULTURE PRODUCTION}

By the turn of the twentieth century, to improve the brewing process using the study of microbes meant applying the techniques of pure culture. Konno Seiji, the original founder of today's moyashi companies Akita Konno Shōten and Kobe-based Konno Shōten in the Meiji period, was a pivotal figure in bringing pure culture of moyashi into the brewing industry. ${ }^{41}$ Born in 1882 , Seiji was one of the sons of a brewing family in Kariwano in Akita Prefecture, the oldest after his elder brother died when Seiji was five. In the snowy town on the Sea of Japan side of Honshū, Seiji's father was the kimono-clad tojji of the family's soy-sauce factory. However, a fire completely destroyed the factory when Konno Seiji was young. ${ }^{42}$ After Seiji completed his studies

\footnotetext{
${ }^{36}$ Murakami Hideya, "Sake to kōji" [Sake and kōji], in Katō, Nihon no sake no rekishi (cit. n. 14), 319-92, on 321.

${ }^{37}$ Saitō Kendō, Tōkyō zeimusho kantokkyoku Saitō Kendō chōsa [Surveys by Saitō Kendō for the Tokyo Tax Office and Inspectorate] (Tokyo, 1905).

${ }_{38}$ Murakami Hideya, "Kinkabu" [Microbial strains], in Kōjigaku [Kōji science], ed. Murakami Hideya (Tokyo, 1986), 48-81, on 57-8.

${ }_{39}$ On the Japanese doctoral degree, see Bartholomew, Formation of Science (cit. n. 30), 50-2.

${ }^{40}$ Saitō Kendō, Hakkō biseibukki [An account of fermentation microorganisms] (Osaka, 1949), 224.

${ }^{41}$ Moyashi is the traditional term for what is now often called tanekoji.

${ }^{42}$ Konno Eiichi (nephew of Konno Seiji), Konno Hiroshi (president of Akita Konno Shōten and grandnephew of Konno Seiji), and Konno Kenji (former president of Akita Konno Shōten and nephew of Konno Seiji), interview by Victoria Lee, 20 February 2012, Kariwano, Daisen-shi, Akita-ken, Japan.
} 
at Akita Middle School, he left the cold northern prefecture to study the scientific principles of brewing. At the time the only college in Japan that had a Brewing Department was Osaka Higher Technical School, located in the heart of the metropolitan merchant capital. ${ }^{43}$

Surrounded by the traditional brewing districts of Kansai, Osaka Higher Technical School's Brewing Department trained technicians from breweries all over the country. The department had been established in 1897 in response to calls from brewers to create an independent subject for brewing, unlike at Tokyo Higher Technical School, for example, where training in the use of microscopes was part of the Applied Chemistry Department. It was rumored that the manager of Osaka Beer (the predecessor of Asahi Beer) prodded the prefectural government's decision by buttonholing a highranking official after a nationwide meeting of the Association of Sake Brewing. ${ }^{44}$ At the school, Konno Seiji studied under Brewing Department head Tsuboi Sentarō. Tsuboi, a graduate of the Applied Chemistry Department from the Imperial College of Engineering (later the Faculty of Engineering at Tokyo Imperial University), saw the department's research as bringing scientific ideals and actual practice [jicchi] together. ${ }^{45}$ At the time, Tsuboi's laboratory was working on the pure culture of tanekojji as well as yeast for application in industry. Tsuboi's advertisement in the back pages of Jokkai in 1902 asking brewers to buy pure-cultured moyashi made by his college laboratory appeared alongside those of established, commercial moyashi makers licensed by the Ministry of Agriculture and Commerce. These commercial firms claimed in their various advertisements that the pure-cultured tanekoji of their respective moyashi makers, the fruit of laborious research efforts and enthusiastically tested technology, drew high praise in the "twentieth-century brewing world." 46 In the picture that both Tsuboi and commercial moyashi makers painted in their advertisements, the application of science placed their products at the cutting edge of the industry.

Konno Seiji graduated in the spring of 1905 and entered Kawamata Shōyu, one of the largest soy-sauce companies in western Japan, whose factory was part of the chimneyed cityscape of Sakai, just south of Osaka. As chief technician of Kawamata, Konno was busily occupied with the mechanization of the factory. ${ }^{47} \mathrm{He}$ was a man so obsessed with the precision of watches that he would make charts of how late each one ran to record its reliability, checking its performance in horizontal and vertical directions.$^{48}$ Apprentices remember that he kept the factory very clean. ${ }^{49}$ That autumn,

\footnotetext{
${ }^{43}$ Akita Konno shōten kabushiki kaisha, ed., Konno moyashi 101nen no ayumi [History of 101 years of Konno Moyashi] (Daisen, Akita, 2011), 26-7.

${ }^{44}$ Hyakushūnen kinen jigyōkai, ed., Hyakunenshi: Ōsaka daigaku kōgakubu jōzō, hakkō, seibutsu kōgakuka [Hundred-year magazine: Department of Brewing Science/Fermentation Science/Biological Engineering, Faculty of Engineering, Osaka University] (Suita, 1996), 10-3.

${ }^{45}$ Tsuboi Sentarō, "Jōzōkai no kakumei jigyō" [Revolutionary projects in the brewing world], Jōkai 23 (1903): 45-8.

${ }^{46}$ Advertisements, Jōkai 10 (1902).

47 Akita Konno shōten, Konno moyashi (cit. n. 43), 27-8.

${ }^{48}$ Ibid., 28-9. On clocks, industry, and work discipline, see E. P. Thompson, "Time, Work-Discipline, and Industrial Capitalism," Past \& Present 38 (1967): 56-97. On the history of clocks and time measurement in Japan, see Yulia Frumer, Making Time: Astronomical Time Measurement in Tokugawa Japan (Chicago, 2018); Takehiko Hashimoto, "Japanese Clocks and the History of Punctuality in Modern Japan," East Asian STS 2 (2008): 123-33.

${ }^{49}$ Kawamata kabushiki kaisha, ed., Murasaki: Sakai no shōyuya Kawamata, Daishō 200nen no ayumi [Murasaki: 200-year history of Kawamata/Daishō, soy-sauce brewer of Sakai] (Sakai, 2000), 90.
} 
while directing the newly opened Kawamata Shōyu Brewing Experiment Station, Konno Seiji isolated an excellent kōji microbe ("Kawamata kin"), which the company began to use for their soy sauce. In 1909 Seiji isolated a microbe suitable for sake, and the following year while keeping his position at Kawamata he and two brothers, Shigezō and Kenkichi, opened a shop (Konno Shōten) in Kyoto and began selling "sake moyashi Konno kin" and other microbes as pure-cultured tanekōji to kōji makers and sake, miso, and soy-sauce companies. The shop soon moved back to Osaka and opened another department for selling tools and machinery, many of which Seiji played a leading role in developing and patenting at Kawamata. Konno Shōten also published a trade journal, Jōzōkai (Brewing world), and later opened a soy-sauce moyashi branch in Sakai and a sake moyashi branch in Nada. ${ }^{50}$

These developments were under way well before the national Brewing Experiment Station in Tokyo developed a method for the pure culture of kojji microbes, on which the related Brewing Society published their first report in $1911 .{ }^{51}$ By then, other companies were already rapidly adopting the use of pure culture. The largest soy-sauce companies in Kantō, such as Noda Shōyu (later Kikkōman), Yamasa Shōyu, and Higeta Shōyu, also began to make tanekojii in-house by the 1910s. ${ }^{52}$ In fact, the head technician at Higeta Shōyu had interned under Konno Seiji at Kawamata before he first began isolating and pure-culturing kōji microbes for soy-sauce tanekōji at Higeta in 1912. ${ }^{53}$ Subsequently, new specialist tanekoji companies appeared in the late $1910 \mathrm{~s}$ and 1920 s to supply smaller soy-sauce makers. ${ }^{54}$

Unlike the yeasts that the Brewing Society worked to maintain, the distribution of $k \bar{o} j i$ microbes was already under the private oligopoly of tanekōji companies, who specialized in preparing what were dried microbial spores that would seed kōji making elsewhere. The tanekōji sector had distant roots in the medieval kōjiza (kōji groups), who held lucrative monopolies over koji making and thereby controlled the source of the entire medieval brewing economy. The shogunate had frequently banned kojji making by unlicensed houses, partly to regulate tax collection but also to minimize brewing activity in order to suppress wastage of valuable rice. Where the monopoly system weakened, specialist kojji makers continued to supply brewing houses who preferred not to make $k \overline{o j i} i$ in-house. ${ }^{55}$

${ }^{50}$ Akita Konno shōten, Konno moyashi (cit. n. 43), 26; Kawamata, Murasaki (cit. n. 49), 88-9.

${ }^{51}$ Narahara Hideki, "Moyashi" [Moyashi], in Murakami, Kōjigaku (cit. n. 38), 32-47, on 35; Chikudō Shō, "Tanekōji ni tsuite (1)" [On tanekōji (1)], Jōzō kyōkaishi 6, no. 7 (1911): 47-52; Chikudō Shō, “Tanekōji ni tsuite (2)" [On tanekōji (2)], Jōzō kyōkaishi 6, no. 8 (1911): 32-41.

${ }_{52}$ Murai Toyozō, "Tanekōji konjaku monogatari" [Story of tanekōji past and present], Shushi kenkyū 7 (1989): 39-44, on 40; Fukuoka-ken shōyu kumiai, ed., Fukuoka-ken shōyu kumiai nanajūnenshi [Seventyyear history of the Fukuoka Prefecture Soy-Sauce Association] (Fukuoka, 1979), 158. Kikkōman also claims that they pioneered pure-cultured tanekojii in 1904 and that the practice spread from there. Nakadai Tadanobu, "Kikkōman ni okeru shōyu jōzō gijutsu kaihatsu no rekishi" [History of the development of soy-sauce brewing technology at Kikkōman], Chiba-ken kōgyō rekishi shiryō chōsa hōkokusho 4 (1995): 1-11, on 4.

${ }^{53}$ Yamazaki Yoshikazu, "Higeta shōyu gijutsu enkaku no kaisō" [Reflections on the history of Higeta Shōyu technology], Chōmi kagaku 21 (1974): 2-6, on 2.

${ }_{54}^{54}$ Murai, "Tanekōji konjaku monogatari" (cit. n. 52), 40.

${ }^{55}$ One such incident occurred in Kyoto in the mid-fifteenth century, when the shogunate attempted to revoke the monopoly law in response to wider discontent, and the struggle with Kitano Tenmangu shrine, which dominated kojji making in and around the capital, resulted in most of the shrine burning down. Koizumi Takao, Kōji kabi to kōji no hanashi [Kōji mold and the story of kōji] (Tokyo, 1984), 105. 
In the Meiji period, as the sake improvement movement grew, more and more brewing companies requested tanekojji from specialist makers rather than making the starter in-house, and by the end of the period almost no sake brewers in Nada were making tanekōji themselves, though in-house manufacture was still prevalent in regions on the periphery of the sake economy. ${ }^{56}$ It had become common practice to shake off the spores of the $k \bar{o} j i$ from a good brew, dry them and use them as seeds in the next round of kojji making; the spores in this case were called tomokojji. However, the original spore starter-at this point sold by tanekōji houses - was tricky to generate.$^{57}$ In theory, if a sake or soy-sauce company built a köji room, it was possible to make original starter spontaneously, by putting steamed soybean and ground wheat (to grow suitable microbes for soy sauce) or steamed rice (for sake) in an open $k \overline{o j} i$ box and then leaving it on the shelf of the kojji room to wait for mold to enter from the air. In a long-standing kōji room, plenty of good kōji microbes should have settled there and be floating in the air. But how could one get to that point, and where did $k \overline{o j i}$ microbes come from? Moreover, how could one maintain good kōji after finding it? With successive culturing, any good kōji would become old, produce fewer spores, and become contaminated by other molds like kekabi or kumonosukabi. The color of the spores would darken and turn black, the mold would have a strange smell, and the taste of the sake or soy sauce would worsen. ${ }^{58}$

It is likely that tanekōji companies who pure cultured $k \overline{o j i}$ microbes were in the minority in the early twentieth century. For example, Kōjiya Sanzaemon in Kyoto, who sold moyashi under the label Biokku and claimed lineage from a kojiza licensed by the Ashikaga shogunate (1336-1573), adopted pure culture technology much later, in $1951 .{ }^{59}$ In the post-World War II period, however, the number of moyashi companies shrank. Compared with the hundred or so that existed at the beginning of the twentieth century, by the last decades of the twentieth century there were fifteen tanekojji companies, of which six distributed nationally. Though the companies were all smallscale, with fewer than fifty employees each, the concentration of the industry implies the level of technology needed to stay competitive. ${ }^{60}$

Konno Seiji's nephew Konno Kenji became head of Akita Konno Shōten much later, by which time the main branch of the company had moved back to Kariwano as a result of rice shortages in Kansai during World War II. Kenji has a childhood memory of watching an apprentice of Seiji's, Ueno Shiejirō, "making genkin," or generating the original starter microbes. ${ }^{61}$ Ueno had not attended a technical school and had learned these methods under Konno Seiji during the war. Starting with a mass of spores floating in water, Ueno used a syringe to deposit a droplet of the spore mixture into a container of pure water, repeating until he had a very dilute mixture. Then Ueno would draw a mark on the cover glass and look at the sterile colored liquid through the microscope, to see whether there was only a single spore on the dish. If there was, he sterilized a piece of filter paper by splashing alcohol on it and used it to suck up the spore. He expanded the single spore into a colony by culturing it on rice grains, in other words making $k \overline{o j} i$

\footnotetext{
${ }^{56}$ Narahara, "Moyashi" (cit. n. 51), 35.

57 Ibid., 34.

${ }^{58}$ Kawamata, Murasaki (cit. n. 49), 86-8.

${ }^{59}$ Murai, "Tanekōji konjaku monogatari”" (cit. n. 52), 42.

${ }^{60}$ These figures are for 1985. Narahara, "Moyashi”" (cit. n. 51), 36.

${ }^{61}$ Konno Eiichi, Konno Hiroshi, and Konno Kenji, interview by Lee (cit. n. 42).
} 
within a flask, using wide-bottomed flasks that Konno Seiji had specially designed to increase the area for culturing. Then he subjected the pure colony to testing, investigating properties such as the formation of proteases, amylases, acid-resistant amylases, and so on. If the colony was strong, Ueno would select it for preserving and, taking spores from that colony, repeat the entire process perhaps hundreds of times. In this manner, by thoroughly investigating weak and strong microbes using the single-spore method, only the microbes with the very best qualities would be propagated and made into genkin. Droplet by droplet, taking spores wrapped in single droplets, one could cultivate them and bring up their descendants.

The single-spore method was also crucial to preserving the selected microbe. Otherwise, when successively cultured, the strain would quickly degrade. ${ }^{62}$ What protected the products of tanekoji makers who employed pure culture methods was partly their reputation, but also the fact that other makers did not have the technology to maintain the strains even if they physically possessed them. The expense of maintaining high-quality strains also meant that brewing factories increasingly preferred to purchase taneköji from specialist makers.

The reason for the swift adoption of pure culture technologies in the tanekojii industry was that they were upgraded versions of technologies that tanekōji makers had already been using. Since the products that they sold were dried microbial spores, they had long followed practices for identifying and isolating "good" cultures, mainly relying on sensory means. By inspecting the color of the spores, one could tell what kind of mold the kōji consisted of as well as how old the kōji was, as the yellow or yellow-green spores tended to darken to brown with successive culturing and with time. From the smell, one could tell how dry the spores were and the method of production. ${ }^{63}$ This varied widely between makers, for example, in the geographical source of the ash used, how they stacked the kojji boxes during culturing, and the way and degree to which they dried the spores. ${ }^{64}$ If the moyashi maker put the spores in his mouth he could make similar distinctions through their taste and hardness. $\mathrm{He}$ could also check them for bacterial colonies. Finally, the maker could actually make $k \overline{o j i}$ and see how smoothly it went and then ask breweries to try out the tanekōji and see how the sake, soy sauce, or miso tasted. By these means, the moyashi maker could select the best spores. Makers had also, since the late thirteenth century, attempted to store, maintain, and propagate the mold cultures as purely as possible by adding special ash. ${ }^{65}$ In a report in 1903, Tsuboi Sentaro noted that if one went to the places where $k \bar{o} j i$ was made, sometimes the workers would first sprinkle camellia ash onto the rice, and then after mixing in the $k \overline{o j i}$ on which were stuck all kinds of microbes and bacteria and bringing the whole thing into the kojji room, somehow only the mold microbes would multiply. ${ }^{66}$ New scientific methods allowed tanekoji makers to fulfill the same aims with a much higher degree of control.

Most important, tanekōji makers and academic scientists not only shared common tools and techniques; they shared similar intellectual concerns. University laboratories, government-run experimentation stations, and the thousands of brewing houses

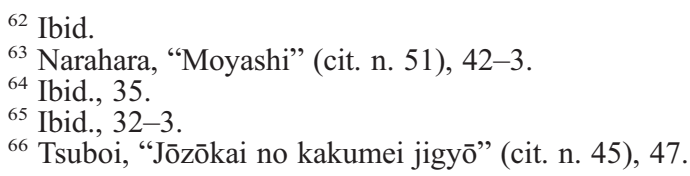


that specialized in tanekōji, $k \overline{o j i}$, sake, or soy sauce shared a concern with isolating, identifying, and preserving individual microbial strains and investigating their properties. Academic scientists depended upon tanekōji makers and other brewers to provide them with their objects of study, the microbes, which they then studied and preserved in a similar fashion. It was the shared intellectual concerns between academia and industry that helped to drive the adoption of new technologies in a dynamic private sector, a sector that in turn shaped the way academic researchers thought about problems and the research objects they used.

\section{THE BOUNDARIES OF THE CELL}

During the same period, the naturalist and folklorist Minakata Kumagusu (18671941) sought to use microbes' variety and life cycles to illuminate the ways in which the identity of the living organism could be understood. Minataka's studies staked out a position that directly opposed the emerging purposes and methods of microbe scientists. In reaction to academic mold studies, Minakata's work stood against the taxonomic fixation on species, against the assumption that microbes should be understood as bounded entities, and against the notion that scholars should be functionary experts instead of tackling more wide-ranging philosophical questions. Minakata was famed internationally for his studies of cryptogams (or spore-producing lower plants that do not bear flowers or seeds), particularly slime molds, which he liked to examine under an old-fashioned single-lens microscope. ${ }^{67} \mathrm{He}$ began collecting specimens during his four-year visit to the United States, beginning at the age of nineteen, during which he traveled from Michigan to Florida and even ventured to Cuba. $\mathrm{He}$ continued collecting over his eight-year sojourn in London from 1892 to 1900, and during the subsequent decades of long walks in the forests of his native Wakayama Prefecture in Japan.

He published fifty-one contributions in the scientific journal Nature, mostly during his time in London. By the 1910s, Nature had begun to reject his letters with the explanation that they were too diffuse. He went on to publish hundreds of essays in Notes and Queries, spanning subjects from the natural sciences to history to ethnography. ${ }^{68}$ Among other things, Minakata was an eccentric in refusing to conform to academic science's sharply emerging disciplinary boundaries. His alternative studies on slime molds cast light on those boundaries, which defined science as a modern institution in Japan, far more than its amenability to exchange with the international scientific community. Together with his followers he amassed a substantial collection of slime molds and continued to send specimens to the naturalists Arthur and Gulielma Lister at the British $\mathrm{Mu}-$ seum over the years.

Minakata held no degrees and worked entirely outside the Japanese academy. He was a vehement activist against the Meiji state's aggressive reach in Wakayama, specifically, the government's destruction of thousands of older forest shrines in order to merge them with large modern shrines, in the campaign to foster Shintō as the

\footnotetext{
${ }^{67}$ Nakazawa Shin'ichi, Mori no barokku [Baroque of the woods] (Tokyo, 1992), 227.

${ }^{68}$ Yoshiya Tamura, "The English Essays of Minakata Kumagusu: Centering on his Contributions to Nature," Japan Foreign Policy Forum 16 (2013), http://www.japanpolicyforum.jp/archives/society /pt20131007043828.html (accessed 23 May 2016).
} 
official state ideology. ${ }^{69}$ As numerous letters to Japanese acquaintances testify, behind Minakata's fascination with slime molds lay his interest in epistemological and metaphysical questions about life. Is there such a thing as a species? What is the nature of life and death?

Minakata came to believe that there were no true species, and that new species and new varieties of slime molds were nothing more than states of variation. In 1928, he wrote in a letter to a disciple that there were few clear true species, and instead there were many intermediates that did not belong under anything. Of those, which were real species, which were varieties, and which were different states? In between similar varieties, there were still more countless intermediate varieties. The more one looked, the more it became clear that in heaven and earth, there was not one thing that could be certified as a species; in the natural world, there was absolutely no such thing as a genus or species. To reach this realization was the point to their painstaking studies. Moreover, Arthur Lister's catalog of slime molds, Minakata pointed out, contained few new species, and rather many new varieties, and these supposedly advanced slime mold morphology. The achievements of slime mold research had become the discovery of new varieties, rather than new species. He encouraged his correspondent not to send away research materials to others but to settle matters at his own leisure - giving up hope of discovery or invention, for to discover a new species was nothing more than child's play. ${ }^{70}$

The ambiguous status of slime molds between the plant and animal kingdoms particularly fascinated Minakata. Despite the slime mold's visually appealing form in the plantlike part of its life cycle, which attracted naturalists, Minakata insisted on the significance of its animal-like characteristics during its other, amorphous phase. $\mathrm{He}$ described the slime mold's ability in its amoeba-like form to extend leg structures and go and swallow up solid bodies. ${ }^{71}$ In a 1911 letter, he wrote that he had studied phenomena of life and death and matters of the soul as they concerned this organism for fifteen years. In a 1931 letter, he related insights from a conversation twenty-two years earlier regarding his slime mold work with an expert Buddhist acquaintance, Tsumaki Jikiryō. In the letter, Minakata described the slime mold's life cycle in light of the Mahāyāna Mahāparinirvāṇa Sūtra, an eschatological text with origins in firstcentury south India. ${ }^{72}$ It was like when the shade was extinguished, light was born and consumed it, and when light was extinguished, darkness was born. It was like when a guilty person faced death, in hell the masses were expectant of one new life; when the guilty person recovered in vitality, in hell people clamored that the unborn child was on the verge of being miscarried; and when the guilty person finally died, the people in hell celebrated the smooth delivery of the child with relief.

In the slime mold's protoplasmic form, it ate rotten wood and dead leaves. After a long time, depending on various fates of light, heat, humidity, or wind, it could not stop at its protoplasmic form and welled up, offshoots becoming stalks, other offshoots

\footnotetext{
${ }^{69}$ On Minakata Kumagusu's protests against the state, see Julia Adeney Thomas, Reconfiguring Modernity: Concepts of Nature in Japanese Political Ideology (Berkeley and Los Angeles, 2001), 188-93; Mark Driscoll, Absolute Erotic, Absolute Grotesque: The Living, Dead, and Undead in Japan's Imperialism, 1895-1945 (Durham, N.C., 2010), 1-21.

${ }^{70}$ Nakazawa, Mori no barokku (cit. n. 67), 253-5.

71 Ibid., 246-8.

72 On Minakata Kumagusu's thought and Buddhism, see G. Clinton Godart, Darwin, Dharma, and the Divine: Evolutionary Theory and Religion in Modern Japan (Honolulu, 2017), 92-103.
} 
clambering up it and some becoming spores, some becoming walls surrounding the spores, some becoming filaments tying stalks, spores, and walls together. In the wind they dried, and in an instant the walls broke apart and the spores dispersed and flew, to someday transform into their protoplasmic form and prepare to propagate in another place. But while not yet dry, if there was a great wind or rain, the offshoots would in an instant cover their tracks and retreat to the original protoplasmic form, avoiding catastrophe by hiding under a tree or leaf. If the weather reverted to fine, the protoplasmic form would well up once again to make spore sacs. Minakata reflected that people scorned the slime mold in its protoplasmic form as a shapeless, phlegm-like semifluid. When under the microscope lens people watched the form bearing beautiful spores, walls, and stalks, they celebrated. If those offshoots once again became fluid and the slime mold reverted to its protoplasmic form, people would think that the slime mold was dying. The protoplasmic form seemed to have no function at all, like it was dead. Yet, Minakata pointed out, it was the protoplasmic form that was active, eating. When the form became stalks, spores, sacs, and filaments, it did not act at all; it was dyingsolidifying and changing into another form. ${ }^{73}$

For Minakata, what the slime mold's life cycle challenged was the independent identity of the organism's life, which biologists in Europe - and later, Japan - had come to characterize as the autonomous interior maintenance of a bounded, organized individual, taking animals as their primary objects. ${ }^{74}$ The notion of life as a self-directing ensemble of functions to resist death went beyond medical or animal studies, since cell theory drew on the same ideas. ${ }^{75}$ Minakata's account offered a different view. A person observing the slime mold under the microscope could see that the life of the slime mold's protoplasmic form, which appeared like the metabolic animals that physiologists dissected, was different from the life of the slime mold's reproductive form, which appeared like the shapely plants that naturalists appreciated. Yet the two lives shared an interconnection that could not be seen from the vantage point of either kind of observer, and which went deeper than both. To Minakata, the slime mold's life cycle illustrated that individual life itself was a superficial phenomenon, and that the interconnectedness of things governed the organism at a more fundamental level.

In contrast, the assumptions about microbes that academic science adopted in the Meiji period allowed scientists to buttress directly the state's vision of fukoku kyōhei (rich country, strong army). For the scientists who imported the foreign concept of the microbe and adapted it for the purposes of rapid national industrialization, the existence of species was not a question in itself. As Christina Matta has shown, in Europe the philosophical foundations for bacteriology had been laid as early as the 1860s and emerged from cryptogamic botany rather than medicine. These developments, she

\footnotetext{
${ }^{73}$ Nakazawa, Mori no barokku (cit. n. 67), 260-2.

${ }^{74}$ On this point I follow the interpretation of Minakata's thought in ibid., 263-9. The literature on comparative anatomy and physiology is extensive; see, e.g., Michel Foucault, The Order of Things: An Archaeology of the Human Sciences (New York, 1970); Foucault, The Birth of the Clinic: An Archaeology of Medical Perception, trans. A. M. Sheridan Smith (New York, 1975); John E. Lesch, Science and Medicine in France: The Emergence of Experimental Physiology, 1790-1855 (Cambridge, Mass., 1984).

${ }^{75}$ William Coleman, Biology in the Nineteenth Century: Problems of Form, Function, and Transformation (1971; repr., Cambridge, 1977), chap. 2; J. Andrew Mendelsohn, "Lives of the Cell," J. Hist. Biol. 36 (2003): 1-37; Laura Otis, Müller's Lab: The Story of Jakob Henle, Theodor Schwann, Emil du Bois-Reymond, Hermann von Helmholtz, Rudolf Virchow, Robert Remak, Ernst Haeckel, and Their Brilliant, Tormented Advisor (Oxford, 2007).
} 
argues, were driven by experimental study, or the aim to apply the methods of the physical sciences in botany instead of relying on morphology alone. It was in this period that Ferdinand Cohn developed a taxonomic system for classifying bacteria into distinct, stable species, based on physiological identifiers where morphological properties were not sufficient. ${ }^{76}$ Subsequently, this intellectual framework became important to agricultural as well as medical science. ${ }^{77}$

For medical bacteriologists, as Olga Amsterdamska has argued, the stability of species was a "grounded assumption" that allowed efficient research strategies for engaging in laboratory investigations on disease, even when scientists knew that there were reasons to question the assumption. ${ }^{78}$ In Japan, the same was true for studies on industrial processes. Laura Otis has observed that the cellular boundary rose as a prominent image in nineteenth-century European medical thought. ${ }^{79}$ Rudolf Virchow pushed a vision of cells as free, self-bounded, self-responsible units in a body, like people in a liberal society. Louis Pasteur's experiments helped drive people to see microbes as a living force, by making germs easily visible to his society and encouraging people to erect barriers against them. Later, Robert Koch's goal of "aggressive intervention in the interest of saving lives" led him to assume a one-to-one specificity between a species and a disease, as well as to ensure pure culture by growing colonies only from single microbes so that the specific identification could be guaranteed. ${ }^{80}$ While Tokugawa-era Japanese, for example, had lacked the language to convey directly the notion of bodily nature as autonomous mechanical necessity, in Meiji Japan scientists adopted European conceptions of cellular identity in their microbial work, enabling their role to serve state intervention in the lives of people and industries. ${ }^{81}$

In the Meiji era, the parallel between species and commodities - between scientists' methodologies for making species of fermentation microbes, and brewers' methodologies for making commercial brands of spores - became a literal one. Scientists, with each new agent they identified as a cause of chemical change, sought to bring the processes of brewing further under control. Their procedures of investigation were like those of tanekoji makers, and unlike those of unsupported naturalists such as Minakata Kumagusu. Federico Marcon argues that a vision of "the subsumption of knowledge under production and the subsumption of scholars under a state apparatus" had already begun to develop in the closing years of the Tokugawa period, with the emergence of the notion of a centralized political economy that preceded and influenced the Meiji vision. But as he also observes, the conception of "nature" as a category that referred

\footnotetext{
${ }^{76}$ Christina Matta, "The Science of Small Things: The Botanical Context of German Bacteriology, 1830-1910" (PhD diss., Univ. of Wisconsin-Madison, 2009).

${ }^{77}$ Similarly, Christoph Gradmann argues that concepts of purity and the stability of species were not prioritized in medical bacteriology until the late 1870s; see Gradmann, "Isolation, Contamination, and Pure Culture: Monomorphism and Polymorphism of Pathogenic Micro-Organisms as Research Problem 1860-1880," Perspect. Sci. 9 (2001): 147-72. On species in immunology, see Pauline M. H. Mazumdar, Species and Specificity: An Interpretation of the History of Immunology (Cambridge, 1995).

${ }^{78}$ Olga Amsterdamska, "Medical and Biological Constraints: Early Research on Variation in Bacteriology," Soc. Stud. Sci. 17 (1987): 657-87, on 667.

${ }^{79}$ Laura Otis, Membranes: Metaphors of Invasion in Nineteenth-Century Literature, Science, and Politics (Baltimore, 1999).

${ }^{80}$ Ibid., 29.

${ }^{81}$ Frederik Cryns, "The Influence of Hermann Boerhaave's Mechanical Concept of the Human Body in Nineteenth-Century Japan," in Dodonceus in Japan: Translation and the Scientific Mind in the Tokugawa Period, ed. W. F. Vande Walle and Kazuhiko Kasaya (Leuven, 2001), 343-63.
} 
to the whole of material and phenomenal reality - as something universal, and distinct from "society" - was new to Meiji Japan, even if analogous conceptions had begun to develop in the late Tokugawa period.$^{82}$ Only in the Meiji period did "nature" come to be a coherent domain, one that industrial and state actors perceived could be exploited toward the goal of capital accumulation.

The modern scientist in Japan specialized in nature as an occupation. In the new ontological separation between "nature" and "society" in Japan described by historian Robert Stolz, the scientist had no particular authority to speak on philosophical and moral questions. ${ }^{83}$ This made him different from the intellectuals of the early modern era, and from thinkers like Minakata Kumagusu, who in the modern period rejected such separations as subjective. Though the microbe came with a set of philosophical assumptions, microbe scientists separated the material from epistemological and metaphysical problems. The Meiji-era social and political order set rigid educational and career paths for these new specialists. ${ }^{84}$ Within the political-economic framework of the state, they were managers of production, like tojji in a brewery. In their studies on fermentation microbes, scientists mimicked the activities of the experts who worked for brewing companies, as they themselves became technical experts who worked for the state.

\section{CONCLUSION}

The surprising convergence of assumptions or procedures from European microbiology, which were imported during the Meiji period, with commercial practices in Japanese traditional industry that had been developing over several centuries is highly suggestive of the ways in which the modernity of scientific institutions is bound up with industrial capitalism. The philosophical foundations that underlay the routes for producing microbes as species found a striking parallel in the goals that drove existent, specialist methods of producing microbes as commodities. Thus, for moyashi makers such as Konno Seiji, the introduction of the microbe as a concept and pure culture as a technique did not fundamentally change the aims of production or its labor organization, though it enabled makers to identify and refine the capacity of molds with greater precision. In turn, protoindustrial and protocapitalist developments from the Tokugawa period found direct expression in Meiji scientific institutions, as the paths for producing microbial commodities and microbial species became equivalent through close exchange - both intellectual and material — between brewers and scientists. Because of this, "microbe" $[\mathrm{kin}]$ referred as much to fungi as bacteria.

Similarly, state policies to promote a capitalist economy co-opted the local initiatives of long-standing experts in industry to improve manufacturing. Newer scientific

\footnotetext{
${ }^{82}$ Marcon, Knowledge of Nature (cit. n. 5), 276-7.

${ }^{83}$ The point regarding the implications for scientific authority within the framework built by the Meiji state is my own. Stolz instead emphasizes the gradual breakdown of this ontological separation and the emergence of an environmental consciousness after the Ashio Mine pollution disaster. Robert Stolz, Bad Water: Nature, Pollution, and Politics in Japan, 1870-1950 (Durham, N.C., 2014), chap. 1.

${ }^{84}$ On the contrast with Tokugawa-era intellectual paths, see Bartholomew, Formation of Science (cit. n. 30), chap. 2; Ellen Gardner Nakamura, Practical Pursuits: Takano Chōei, Takahashi Keisaku, and Western Medicine in Nineteenth-Century Japan (Cambridge, Mass., 2005), 166-70; Janine Tasca Sawada, Practical Pursuits: Religion, Politics, and Personal Cultivation in Nineteenth-Century Japan (Honolulu, 2004), chap. 4.
} 
experts had an even clearer role to play in the political economy of the Japanese state. The government took an interventionist approach to what it saw as Japan's capital-poor, late-developer economy. Modern science was institutionalized at the same time as a network of imperial universities, technical colleges, national and prefectural experiment stations and research programs, scholarly and trade journals, and industrial associations took shape around government policies. This resulted in a social constellation of scientific expertise in Japan that did not make a strong distinction in definition or hierarchy between science and medicine, engineering, or agriculture. As highlighted by the contrast between scientific questions and the goals of inquiry of the nonacademic naturalist Minakata Kumagusu, the new conception of "nature" enabled the cellular division between the independent living force and the mastered environment and made scientists managers of production. Thus the scientist did not have special authority to speak on metaphysical and epistemological issues, unlike the early modern intellectual. While microbes became living workers, the modern scientist became a technical expert for the state. 